\title{
Morphological and GIS-based land use Analysis: A Critical Exploration of a Rural Neighborhood
}

\author{
"Dr. OLUWAGBEMIGA PAUL AGBOOLA ${ }^{1}$,Dr. MOHDHISYAMRASIDI ${ }^{2}$,Dr. ISMAIL SAID ${ }^{3}$, MA. SAMSON OLUTAYO
} ABOGAN ${ }^{4}$, MA. ADEBAMBO STEPHEN ADEJUWON ${ }^{5}$

'Department of Architecture, Faculty of Environmental Studies, Osun State College of Technology, P.M.B.1011, Esa-Oke. Osun State. Nigeria.

${ }^{2,3}$ Department of Landscape Architecture, Faculty of Built Environment, UniversitiTeknologi Malaysia, Postcode 81310, Johor Bahru, Johor. Malaysia.

4.5Department of Urban and Regional Planning, Faculty of Environmental Studies, Osun State College of Technology, P.M.B. 1011, Esa-Oke. Osun-State. Nigeria.

'E mail: agbofavour41@yahoo.com , 2E mail:hisyamrasidi@gmail.com , ${ }^{3} E$ mail:ismailbinsaid@gmail.com, 4E mail: agbofavour41@yahoo.com

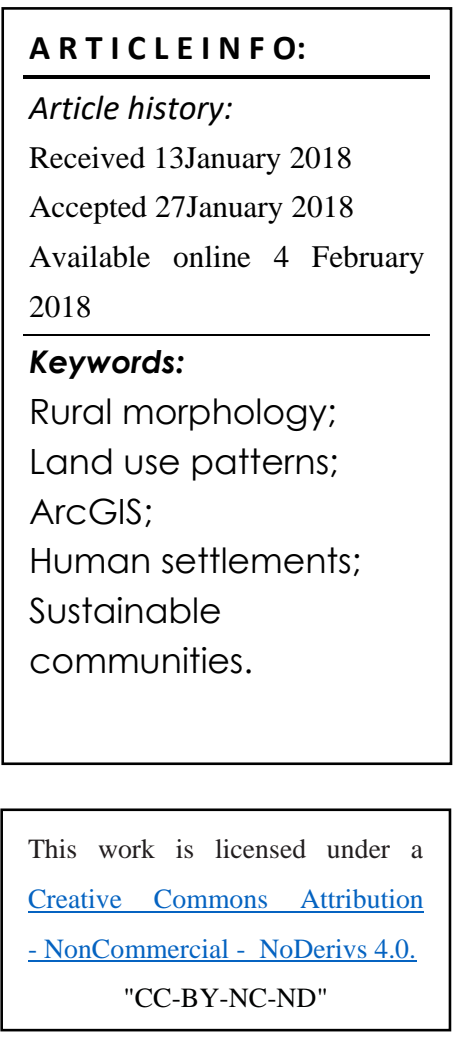

\begin{abstract}
A B S T R A C T
The significance of neighbourhood in hosting a group of dwellings units and possessing adequate communal facilities could not be overemphasized in the study of people and place relationships. There are two main objectives of this study: (i) to study the neighbourhood's associated challenges through the size, growth, and land use distribution, and (ii) to investigate the perceived inhabitants' activities pattern within the neighbourhood. The objectives are explored through a morphological and GIS-based land use analysis of a rural neighbourhood in South-west, Nigeria. The town is studied in three transformation phases, dating back to five decades using ArcGIS version 10.3. The 1st phase spanned between the year 1910 to 1959, while the 2nd and 3rd phases ran through the year 1960 to 1999, and year 2000 to 2015 respectively. The exploration in this study is to document the diverse neighbourhood challenges, features, and prospects, which remain uninvestigated in the case study area for the past years. The first finding revealed that some challenges needed to be resolved in a bid to meet the residents' current basic needs. The second finding indicated that the rural settlements in Nigeria emanated from the residents' adaptation to the environmental conditions, cum transformation through human activities. Meanwhile, the third finding established that the human settlements evolved in connection to the local socioeconomic, recreation and religious virtues of the traditional marketplace (Oja). In conclusion, human historical and social influences play a significant role in ameliorating the challenges associated with the spatial developments of the settlements. The implication of the study becomes vital to the major stakeholders and professionals in the built environment on the significance of enhancing the sustainable communities in Nigeria.

JOURNAL OF CONTEMPORARY URBAN AFFAIRS (2018) 2(2), 106-121.
\end{abstract}

https://doi.org/10.25034/ijcua.2018.4675

www.ijcua.com

Copyright (C) 2018Journal Of Contemporary Urban Affairs. All rights reserved.

\section{Introduction}

Neighbourhood as a place in built environment refers to a fractional part of a city or suburban area which offers a residential environment and allied facilities for lower percentages of residents' population (Nadeem, et al., 2013).In other words, the neighbourhood could be perceived in terms
*Corresponding Author:

Department of Architecture, Faculty of Environmental Studies, Osun State College of Technology, P.M.B.1011, Esa-Oke. Osun State. Nigeria.

E-mail address: agbofavour41@yahoo.com 
of residents' populationcapacity that may range from 2500 to 25000 residents, with the sizes up to 30 acres (Nadeem, et al., 2013). The neighbourhood environment such as rural town and villages can be studied in its totality of the existing surrounding conditions (Aydin \& Buyuk, 2014; Berk, 2005). Similarly, it could be seen as a recognized boundary whose characteristics are derived primarily from its components. The components involve physical, cultural, and social aspects. Rural neighbourhood environment could be described as a fractional key node of activities within a portion of a suburban area serving as a residential environment equipped with necessary facilities for a fewer percentage of residents' population (Agboola, Rasidi\& Said, 2016). Rural neighbourhood indicates a connection between the residents' population, the degree of its remoteness, and physical features in comparison to what is obtainable in urban or city centres (Salamon \& Mac Tavish, 2009). The authors acknowledge, rural as perceptual functions hinge on the population size of the residents and parameter of such locality.

The meaning of rural in this study is coined as a place with fewer agrarians' population of residents having a specific local identity. In this vein, rural neighbourhood according to Duxbury and Campbell (2011) could be ascertained based on a variety of characteristics such as population density and size, socioeconomic characteristics, residents' status, the level of development, and cultural affinity. The primary function of the neighbourhood is to acts as a link between the physical and social dimensions of shared and liveable spaces (Kazmierczak, 2013).

Recent development in the field of rural and urban design, landscaping, architecture, engineering sociology, urban geography among few have called for proper exploration of neighbourhood and morphology concepts with respect to its size, design, transformation, and planning.

Morphology is described as the formation of plots, buildings, use, streets, plans, townscapes (Gordon, 1984). The significance of morphology is reflected largely in that it enables the documentation of spatial aspects of urban and sub-urban developmental viewpoints. In the words, it assists in producing concepts and generalizations related to the character and classification of land use within the suburban area, and to the spatial interactions of cities growth, through internal structure and processes (Goodall, 1987; Herbert \& Thomas, 1982). In addition, morphology is useful in solving some urban and rural planning related challenges, and appraisal of features and prospect by the decision makers in the built environment (Whitehand, 1987). Historically, the planning idea originated from Howard's garden city movement (Kallus\&Yone, 2000; Spreiregen, 1965) when efforts were geared towards combating problems associated with excessive use of automobiles for daily movement and suburbanization during the 20th and 21st centuries (Nadeem, et.al., 2013).

While affirming the associated landscape challenges in Nigeria, Onwuanyi, (2017); Fadamiro \& Atolagbe, (2006); Officha, Onwuemesi\&Akanwa, (2012) and Agboola, Zango\&Zakka (2015b), submitted that the unplanned land use experienced in most Nigerian neighborhoods has affected the adequacy of the landscapes in diverse ways. Therefore, it becomes imperative in studying the transformations in the physical spatial conditions and development pattern of a typical rural town in Nigeria. This is a view of proffering solution to the associated challenges in land use activities.

The objectives of this quantitative and qualitative study focus on the followings: [i] studying the associated challenges with the town through the size, growth, and land use distribution [ii] exploring the perception of the inhabitants (stakeholders and professionals in the built environment) on various activities pattern within the town. The two objectives will explore residents' perception of the quality of neighbourhood land use provisions and transformation in physical development of the neighbourhood. Research questions will answer the following: [i] what are the factors that contributed to the transformation of the case study neighbourhood? [ii] Does the quality of the rural setting affect the perception and interaction of community residents? Understanding the existing morphology of a settlement would constitute a vital factor towards creating an 
appropriate future developmental intervention. This would, therefore, possess a veritable tool for the rural planning and design in Nigeria.

\section{Review of literatures}

\subsection{Geographical Information System, Morphological spatial Analysis and Land Use Planning}

The most useful applications of Geographical information system (GIS) is for planning and management of the land-use suitability mapping and morphological spatial analysis (Brail and Klosterman, 2001; Collins et al., 2001). Notably, the land-use suitability is targeting at identifying the most appropriate spatial pattern for future land uses taken into cognizance the specify requirements, preferences, and predictors of some residents' activities (Collins et al., 2001). Various past studies have adopted the GIS-based land-use suitability analysis in a wide variety of situations including landscape evaluation and planning (Miller et al., 1998), and viable regional planning (Janssen \& Rietveld, 1990).

In the same vein, plethora of studies have been initiated towards solving neighbourhood related problems such as: improving residents' sense of community, improved residents' social interactions within the neighbourhood, provision of adequate security, improved neighbourhoods' environmental pollution, and health problems (Francis et al., 2012; French et al., 2014; Middleton, 2010; Bonilla 2013; Peter et al., 2010; Song \&Knaap, 2003; Broadbent, 1990). Improved general features of neighbourhood lead to the new urbanism that enhances the design of high density, and good neighbourhoods transportation network. This could also target social cohesion and environmental sustainability (NU, 2002; Rubenstein, 1987).

Another concept of eco-towns promotes the design of environment-friendly neighbourhoods with zero-carbon buildings (Barclay, 2011; Nadeem et. al., 2013). Likewise, Berk, (2005) opined that residents' activities and continuous lifestyles formed parts of the basic factors that shape the social environment. This issue was further argued by Meenakshi, (2011) as the causes of segregation in the social environment as against the physical neighbourhood environment.

\subsection{Components of Rural neighbourhood and its Morphology}

Neighbourhood essential components provide natural and cultural features to improve community infrastructure, in which its social status promote neighbourliness. According to Galster (2001), neighbourhood consist of [i] structural characteristics such as residential and nonresidential buildings with various scale, materials, design, and landscaping, [ii] infrastructural characteristics incorporating roads, sidewalks, streetscaping, utility services, [iii] demographic characteristics of the residents population, hinges on age distribution, family composition, ethnic, and religious, [iv] class status characteristics of the residents' population compositions, [v] environmental characteristics showing the degree of land, air, water, noise pollution and topographic features, [vi] social interactive characteristics, including quality of interpersonal associations and residents' perceived commonality, [vii] residents' sense of identification with place, and historical significance of buildings. In view of this, organised settlement enhances users' opportunities and sustainability of the environment (Nasuh, 1993; Agboola et. al., 2015 b).

However, the literature suggests that a neighbourhood unit should be socially and environmentally sustainable in terms of provision and location of residential accommodation, public facilities, commercial areas and utility services (Bramley\& Power, 2009; Dave, 2011). In the same vein, neighbourhood planning should have its aim rooted in the provision of essential amenities capable of enhancing ethnic's interactions and maximum utilization. Shaping attributes of the neighbourhood in multi-ethnic groups should constitute an equal right of access, right of use and equal ownership or control (Megalhaes, 2010). The cultural activities influence the transformation process and then impacts on the change of physical structure social value (Boblic, 1990; Rapoport, 2004; Karakul, 2009). People as the users of built environment react to the transformation process 
that appears in various ways; such resistance, acceptance, re-adoption, and creation new meanings. These could be traceable to the changes in the physical elements as well as the spaces arrangement (Rapoport, 2004; Ganis, 2009).

Meanwhile, the rural neighbourhood composed of diverse open green spaces enabling recreational, religious, social, aesthetic, psychological and economic activities (Kaymakli, 1990; Akinci, 1996; Yildiz, et al., 2011, Agboola, et. al., 2015a). The morphological changes manifest in terms of the social, environmental and economic context that showcased the effect of human cultural actions which culminated in the formation and transformation of neighbourhood built environment depicted in Figure 1.

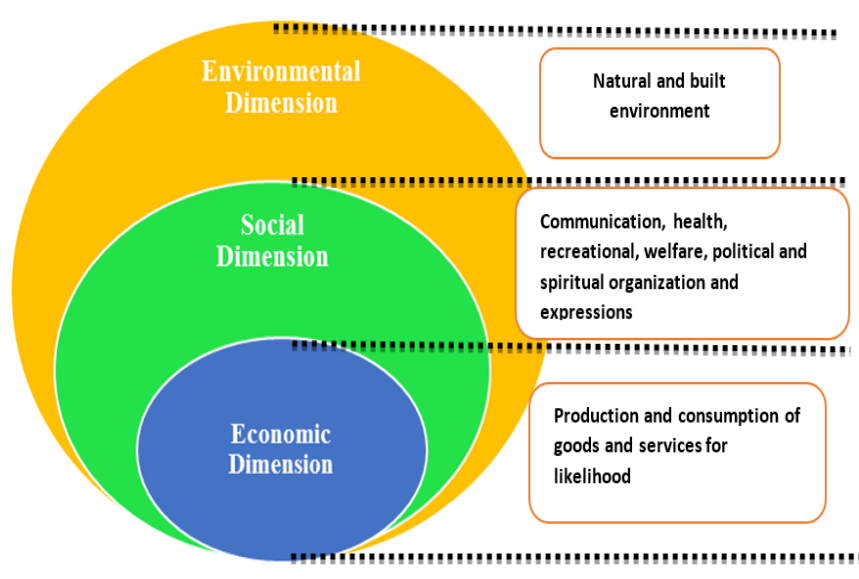

Figure 1. Dimensions of Neighbourhood formation and transformations. Adapted: Pillai, (2013)

Rural morphology dwelt with the various forms of historical approach in relation to the developmental processes of diverse historical periods. The approach explains in details the relationship between the social processes and the observed physical development. An environment where community residents live is surmised into natural, artificial, and social areas (Aydin \&Büyük, 2014). It is argued in this study that the artificial environment relates to the physical environment as evolved by the human requirement that changes over time. The social environment is coined as places meant for human social interactions. And lastly, the artificial environment is the one influences man-made features such as buildings, roads, and other land features. According to Zhang and Li, (2012); Arianeet. al., (2005) neighbourhood environmental characteristics consists of accessibility, amenities, sociability, aesthetics, safety, and policies. The characteristics of which can either to enhance or discourage people's perception and influenced by usage, shared experience, and gainful opportunities derived (Kazmierczak 2013; Peter, et. al., 2010).

In other perspectives, peoples' interest has been shifted towards encouraging communities and identifying the heritage values of their locality. For instance, in England communitybased work is being advocated by the Common Ground organization which was saddled with initiatives to preserve the distinctiveness of localities. The Common Ground (2009) roadmap project recorded a huge success in uniting local communities and mapping the significant aspect of a place. In Australia, as reported by Stephenson (2010), the Commonwealth government has promoted a technique of cultural mapping aiming at helping communities support the cultural diversity for economic, social and regional development (Commonwealth Department of Communications and the Arts, 1995). Comparing their motive with the Common Ground (2009) their methodology involves encouraging community groups to record and conserve their culturally important resources through various means, such as histories, thematic walks, or improvement schemes.

\subsection{Rural neighbourhood services, facilities and Features}

The rural services and facilities could be categorized as primary and secondary. Primary services and facilities include a general food store, post office, bank, libraries, health centre, and green space such as village green, green street edges. Others include public toilets, public seating, and transport stops. The secondary services and facilities include open spaces like market squares, parks, and recreation grounds, and community facilities such as a stadium. Other includes road lighting systems, traffic signals, domestic water systems, sanitary sewer systems, parks and recreational facilities, public schools, police and fire protection buildings. These are 
essential elements useful in providing a livable community, transformations, and enhancing the quality of life (Massam, 1993).

Two groups of services are iterated by Jenks and Jones, (2010). The first group represents indispensable elements called infrastructures such as transportation (streets and roads networks), water supply networks, sanitation, drainage, solidwaste management, electricity, and telecommunication. The second group includes urban services and facilities such as educational, health, commercial, industrial, administrative, cultural, religious, social services and green space. Winter and Farthing, (1997) identified local neighbourhood services and facilities in the United Kingdom context and iterated the compositions of a food shop, post office, pub, supermarket, primary school, and open space. Other services that need frequent access include a chemist, restaurant (Burton, 2000a), bank or building a society (Barton et al., 1995) and community centre (Dempsey et al., 2009). Empirical study has reinstated that the environment is capable of encouraging peoples' physical activity (Goldstein, 2002). According to Onibokun, (1973), a neighbourhood in Nigerian context encompasses physical, social and psychological variables. Consequently, the neighbourhood acts as meeting and connection place make a significant contribution towards fostering community identity, social interactions, and community revitalization. In another perspective, the characteristics and features of neighbourhood possess an ideal place for communal interaction (Aydin and Büyük, 2014). The Nigerian neighbourhood transformation before and after colonialization has affected by people's culture in the society in recent time. Consequently, the physical and social characteristics could help concretizing a proper understanding of the built environment which has affected the socio-cultural structure of the economic and general conditions of villages.

The neighbourhood environment characteristics in Nigeria as presented in Figure 2 could be grouped as natural, artificial, and social characteristics. Meanwhile, the artificial explained in details the physical environment evolved by people over a considerable period of time. The artificial environment is influenced by buildings, roads, and settlement styles. Following this, the social environmental characteristic relates to places where people interact, and also hinged on the residents' socioeconomic prosperity, cultural attachment, and functional attributes. Meanwhile, personal and social identities of residents such as ownership, belonging, tolerance and respect determine the neighbourhood identity character (Aydin and Buyuk, 2014).

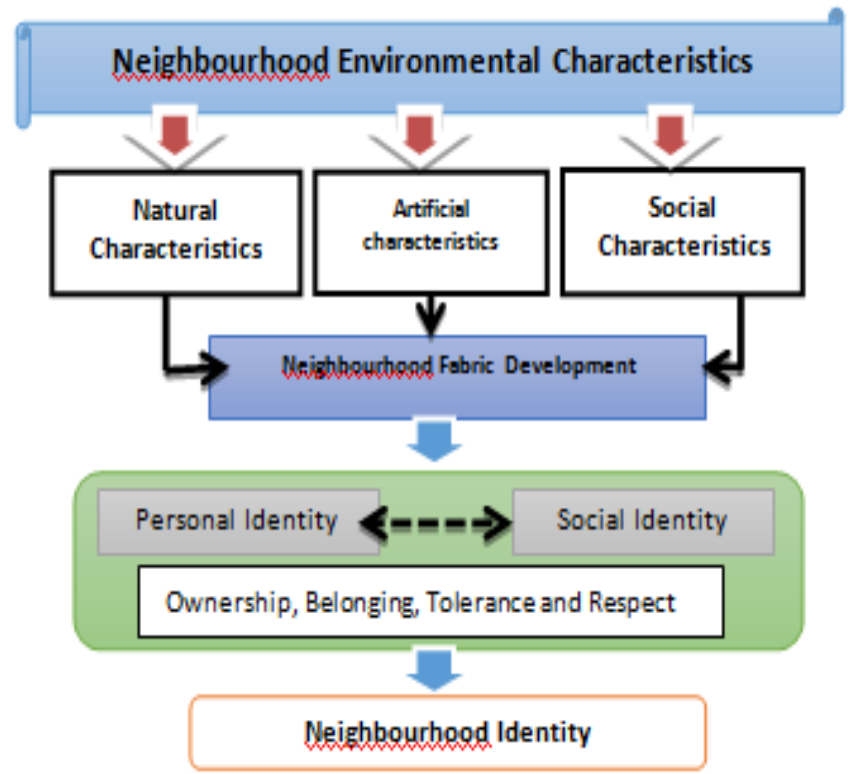

Figure 2.Neighbourhood characteristics. Adapted from Aydin and Buyuk (2014)

\section{Rural Settlement Pattern in Nigeria}

A settlement is a collection of buildings where inhabitants live and earn their living (Ahmed, 2009; Olawepo, 1999). However, the settlements vary in size from small hamlets to large cities. Rural settlements according to Weir and McCabe (2012), are areas with relatively low development densities. A rural settlement pattern inferred the manner in which buildings and other forms of structures are distributed in a particular location. The pattern is of significant interest to the geographers, historians, and the anthropologists through the provision diverse level of community development over a considerable period of time. Settlements are viewed as a reflection of structural relationships among the architectural, cultural, and social perception of the environment (Aydin \&Büyük, 2014; Daniel and 
Hopkinson, 1992). In this vein, rural settlements in Nigeria are regarded as settlements with less than 20,000 people and whose population predominantly engages in primary agricultural production (Aderamo \& Magaji, 2010).

Hosts of factors influence settlement pattern worldwide (Centanni, 2017; Okoro, 2012; Ahmed, 2009). The first is the economic and human physical influences. In this case, the settlements locations allowed maximum communication between different settlements and increased trade. The second relates to the social factors. These include relief, transportation, climate, drainage, groundwater supply, defense and government policies. The third connected to the ethnic and cultural factors. These include aspects of caste, community, ethnicity, and religion. This leads to social segregation and fragmentation of a settlement into several units. The fourth is the historical or defense influences. In the past, mostly border areas of north-western plains were conquered or attacked frequently by outsiders. These factors culminated in the type and spacing of dwellings. The three major forms of settlements as presented in Figure 3 include the nucleated, linear and dispersed settlements.

\subsection{Nucleated settlements}

These are settlements that are formed at crossroads or route centres, comprising a large number of houses clustered around a central point such as a market square. They form a commercial nerve of the neighbourhood along a river or road.

\subsection{Linear settlements}

These are settlements with groups of houses arranged in a linear pattern along a transportation artery. They may not comprise any commercial structures, unlike the cluster settlements. The settlements incorporate the structures that are arranged in a role or line form usually along a river or road seacoast, river valley, mountain ranges. Linear settlement often time developed in response to certain convenience or proximity to transport route among others.

\subsection{Dispersed settlements}

These are settlements that have no obvious centre in which the structures are spread out or scattered over a considerable expanse of land from which the occupants derive their livelihood. They are also known as isolated settlements in which the buildings are spread out in a scattered form. This type of settlement is often formed in a remote or sparsely-populated area. Disperse settlements pattern are often associated with agricultural activities in a farmland region.

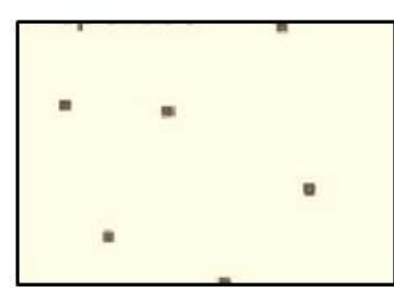

Dispersed settlements

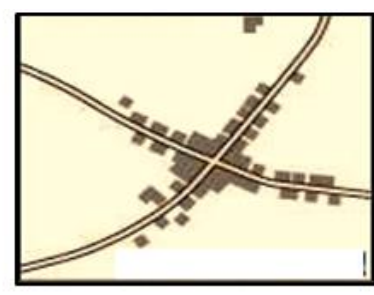

Nucleated settlements

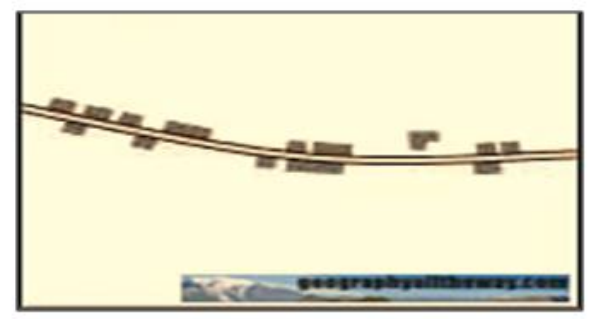

Linear settlements

Figure 3.Three forms of human settlements. Source: www.google.com

\section{Research method, measurements and data analysis}

For planning and management, the most commonly used applications of GIS are the land use suitability mapping and analysis (Brail\&Klosterman, 2001; Collins et al., 2001; Herzele \& Wiedemann, 2003). On a wider scope, land-use suitability analysis through the GIS application has the potential to provide a useful monitoring tool towards the use of neighbourhood green spaces and their changes (Herzele\& Wiedemann, 2003). Similarly, the procedure is capable of appropriating adequate spatial pattern for future land uses in a bid to establish specify requirements, preferences, or predictors of some activity (Hopkins, 1977; Collins et al., 2001).

Morphology is often used to present the changes in the physical and spatial transformation of landmark features in landscape architecture. It has helped in depicting a graphical 
representation of neighborhood changes and enables the calculation of the time wise increase in area spatial expansions. This study adopted morphological method as previously studied by some scholars such as Chen (2011); $\mathrm{Na}$ et al., (2009) and Doralti (2004). The increasing use of Geographic Information Systems (GIS) provides objective measures of comprehension of types and other neighbourhood accessibility measures such as diversity of land use. Therefore the morphology procedures involved the use of maps to ascertain the development and changes in the physical and spatial patterns of neighbourhoods.

Three periods were considered in this study namely: colonial period of pre-independence (the year 1910-1959); the post-colonial period after independence (the year 1960-1999), and modern movement in landscape architecture (the year 2000-2015). The analysis procedures included (i) gathering, collection, and updating of existing features and elements of the neighborhood through on-spot assessment, (ii) the maps were produced based on the timewise periods and digitized by using AutoCAD software (version 2012). The digitizing was done for the purpose of exportation into the ArcGIS version 10.3, and for subsequent mapping, (iii) the maps weresuperimposed to deduce the changes in the spatial development and features. In line with the previous study of Malczewski, (2004); geographic information systems were used to determine the various land-uses of the neighbourhoods such as (i) areas covered by the market square as commercial zone, (ii) residential and government coverage areas, (iii) educational institution coverage areas, (iv) religious coverage areas, and (v) green and open space coverage areas. The procedure adopted for the evaluation of the neighbourhood land-use areas of the case study town. Summarily, the examination is based on the physical form of the town, taken into cognizance the link between the physical form and socio-cultural context. The mapping of the neighbourhood is a systematic approach targeting the identification and classifications of a community's cultural resources (Rowe, 2012).

Perceived neighborhood characteristics and preferences parameters were adapted from
Handy et al., (2004). The study adopted a quantitative research method using relative Importance Index (RII) to analyze the collated data using a Likert scale. The parameters considered include (i) rating of the present conditions of the neighbourhood and adjoining land features encourages easy accessibility (human and vehicular access, RPN1), (ii) rating of the present conditions of the neighbourhood that encourages safety via quietness and low crimes [RPN2], (iii) rating of the present condition of the neighbourhood that encourages interactions (socialization) among all groups through provision of benches, walkways etc [RPN3], (iv) rating of the present condition of the neighbourhood that encourages peoples' attractions through the level of its cleanliness, housing styles and streets' green landscapes [RPN4], (v) rating of the present conditions of the neighbourhood that encourages lots of off-street parking such as garages and drive ways [RPN5].

Respondents (Stakeholders and professionals in the built environment residing in the community for more than two years) were purposively sampled and requested to rate their level of agreement or disagreement with the series of statements on a five-point scale from strongly disagree [1] to strongly agree [5]. Relative Important Index (RII) was appropriately used to cross-compare the relative Importance index among the perceived constructs by the respondents. The formula adopted for relative importance index (RII) is in line with past studies of Agboola\&Salawu (2015) and Agboola, et al., (2017) as follows:

$$
\mathrm{RII}=\frac{\sum f x}{\sum f} \times \frac{1}{k} \quad \ldots \text { eqn. } 1
$$

Where:

RII = Relative importance index

$\Sigma \mathrm{fx}=$ the total weight given to each attribute by the respondents

$\sum \mathrm{f}=$ the total number of respondents in the sample

$\mathrm{K}=$ the highest weight on the Likert scale which is 5

\section{Study areas}

The geographical location of SouthWesternNigeria as depicted in Figure 4, lies between the parallels $5.86^{\circ}$ and $9.22^{\circ}$ North, and 
between $2.65^{\circ}$ and $5.72^{\circ}$ East with an estimated area of about $181,300 \mathrm{~km}^{2}$ (Atanda, 2007). South West Nigeria has six states; Ekiti, Lagos, Ogun, Ondo, Osun, and Oyo. It is majorly a Yoruba speaking area, although there are different dialects even within the same state. The weather conditions vary between the two distinct seasons in Nigeria; the rainy season (March - November) and the dry season (November-February). The dry season is also the bringer of the Harmattan dust; cold dry winds from the northern deserts blow into the southern regions around this time. ljebu-jesa as the case study neighbourhood lies on Latitude: $7^{\circ} 40^{\prime} 57.61^{\prime \prime} \mathrm{N}$; Longitude: $4^{\circ} 48^{\prime}$ 51.70" E. ljebu-jesa is the capital of Oriade Local Government area in the Osun State of Nigeria. It is a commuter city with connections to Ekiti State on one side, Ondo State on another and it has a border with the famous llesatownship. The area is surrounded by towns such as Iwoye-jesa, llokojesa, Ere and ljeda.

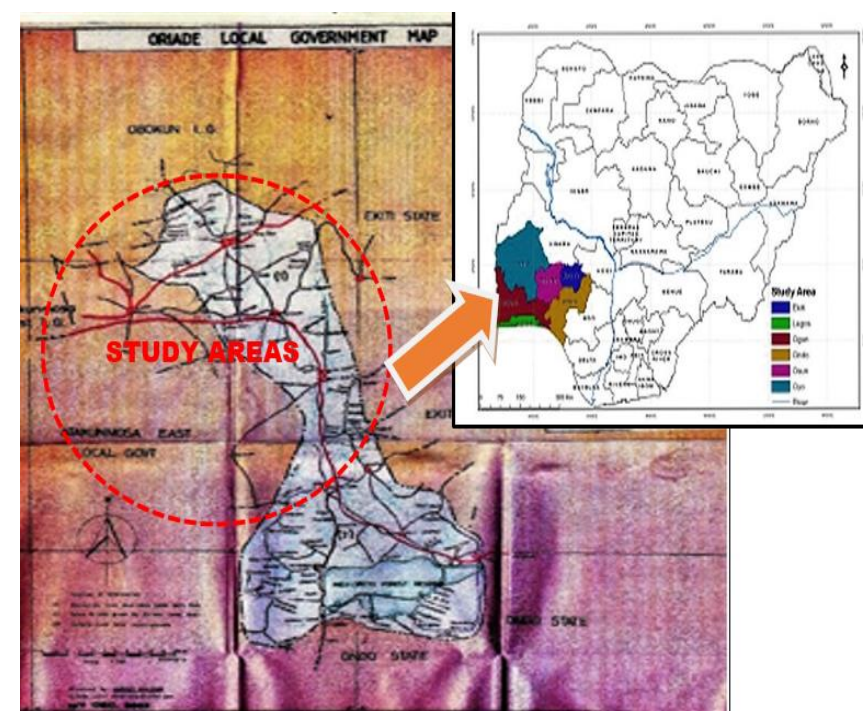

Figure 4. Map of the study areas and its position in Nigeria.

Source: Agboola et. al., (2018) and www.google.com

\section{Results and discussions}

\subsection{The transformation in the town's size, growth and land use distribution system}

The nature of planning during the ancient period was such that it was undertaken by traditional leaders in consultation with community members based on their social-economic needs. The developments were in form of haphazard with crooked and irregular lanes ended up at wide open space at the centre of the settlement. The open spaces were used as marketplaces (oja) and meeting grounds for deliberations on community issues. This early development comprised sub-divided compounds and occupied by related lineages were in clustered form with small lanes and streets in between them. The rationale for such spatial configuration was to protect the inhabitants from external aggression. Humans operate on various tangible and intangible elements of cultural dimensions. Figure 5; identify the comparison of the land use for the three transformation periods of the ljebujesa built form.

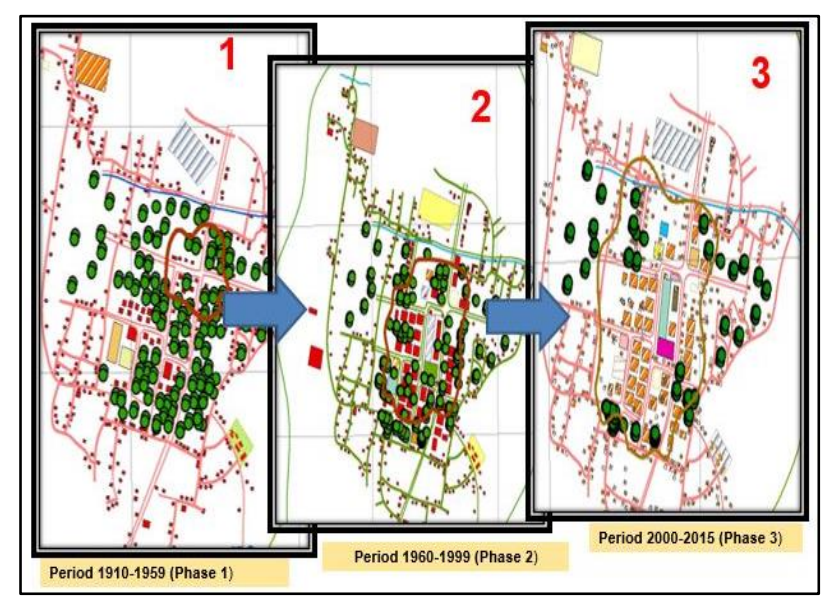

Figure 5. Comparison of the land use for the three transformation periods of the ljebu-jesa built form.

\subsubsection{Period 1910-1960 (Phase 1)}

This historic period covers almost fifty $(50)$ years of existence of the town. Meanwhile, the period is classified as pre-colonial and colonial periods of the open space's planning in Nigeria (Oduwaye, 1998). At the same time, this period is associated with the existence of traditional landscape. The spatial characteristics of this period associated with the existence of about $2.62 \mathrm{~km}^{2}(4.74 \%)$ of both the residential structures and government structures (Figure 9). The greatest greenery and open space areas of $48.92 \mathrm{~km}^{2}(88.41 \%)$ were available during this period as shown in Figure 7. In view of this, the location of the market square (Oja) and shrine (ojubo-orisa) at the core of the neighbourhood created cluster types of settlements pattern. There were no planning 
concept and expertise at this period, as the pacesetters and founders were King (Oba), chief (Oloyes), and the community residents. Therefore, the coverage area of the market square (Oja) was about $1.04 \mathrm{~km}^{2}$ (1.88 \%) with virtually no spectacular facilities (Figure 8). Hence, the general level of development of the neighbourhood was at lowest ebb as shown in Figure 5. It is noteworthy to state here that there was virtually little or no human and vehicular congestion at this period.

\subsubsection{Period 1960-2000 (Phase 2)}

The period of 40 years refers to a postcolonial period, after independence associating with researchers' awareness on industrialization, urbanization, planning, and preservation (Falade 1989; Oduwaye 1998; Oyesiku 1998). Meanwhile, others include an appreciation of open space greeneries. Historically, the industrial revolution seems to have negative and devastating effects on the environmental landscape during this transformations period. Therefore, this period informs peoples' awareness of the interaction between man and nature, which brought open space planning concept. This equally acted as a bridge between the past and present-day relationships between the society and its environment (Rescia et al., 2008). Similarly, scholars began to advocates the need for the establishment, management, planning, and design of landscape and built environment in general. Hence, Figure 5 and Figure 9 revealed an increase in the percentage of land use features due to the various factors. First was the incorporation of private residential, religious (church and mosque) and commercial structures (banks, shops, eateries etc) which led to a reduction in green space from $48.92(88.41 \%)$ of phase 1 to $39.92(61.07 \%)$ of phase 2. This phase 2 reflect (i) increase in the percentage of the new religious structures [Figure 11] and educational structures [Figure 10], (ii) increase in areas occupied by market square (Oja) to about 1.83 $\mathrm{km}^{2}$ [2.80\%] from $1.04 \mathrm{~km}^{2}$ [1.88\%] experienced between Year 1910-1959 as shown in Figure 5. (ii) Increase in road and street networks and connectivity [Figure 7].
Hence, it obvious that a drastic change of environment and physical character exist at a higher proportion than the former base map features (Figure 5 and Figure 9). In addition to this, reduction in the percentage of greeneries has affected the human appreciation of open space beautifications. This was also traceable to the increase in the population of the community residents at this period. According to the 1991 census (the Final result of 1991 National population census of Nigeria), the population of ljebu-jesa was 11,680. There was an increase in the population by the year 1996 projected population to about 13,314 indicating an increase of about $12.27 \%$ (Agboola, 2016).

\subsubsection{Period 2000-2015 (Phase 3)}

The period spans through fifteen (15) years, which solidified the advent of the modern movement in landscape planning and management in Nigeria. The appropriate consolidations of ecological approach towards landscape management were initiated. Also, advocacy was intensified on concern for landscape as cultural heritage. Researchers such as Falade (1989); Oduwaye (1998); Oyesiku (1998); and Adejumo et al., (2012) advocating and taking cognizance of the interrelationship between the people and their environment. Consequently, the increase in the awareness of scholars on the significance of the landscape qualities, design, and management in Nigeria is noted at this period.

The above scenario led to the general debate on the term sustainable development, which could be in form of physical or social developments. This period is experiencing an upsurge in residents' population of about 22,499 (the year 2015 projected population) amounted to about $40.82 \%$ (Agboola, 2016 and Figure 9). It is obvious that greater percentages of the green areas seen in phase 1 of development that spanned years 1910 to 1959 and that of phase 2 between years 1960 to 1999 have been taken over by residential, educational and commercial structures (Figure 5). This led to a reduction to about $28.48 \mathrm{~km}^{2}$ (32.09\%) in of the land use coverage by the green space and open space areas in phase 3 of the neighbourhood development (Figure 6 and Figure 9). In other 
words, the expansion/urbanization has further created more spaces for (i) area covered by market square as commercial zone with $2.04 \mathrm{~km}^{2}$ [2.30\%], as depicted in Figure 8, (ii) area covered by residential structures and Government structures with $29.02 \mathrm{~km}^{2}$ [32.75\%] as depicted in Figure 6, (iii) areas covered by educational institutions with $16.38 \mathrm{~km}^{2}$ [18.45\%] as shown in Figure 10, (iv) religion coverage areas with 12.29 $\mathrm{km}^{2}$ [14.41\%] as revealed in Figure 11.

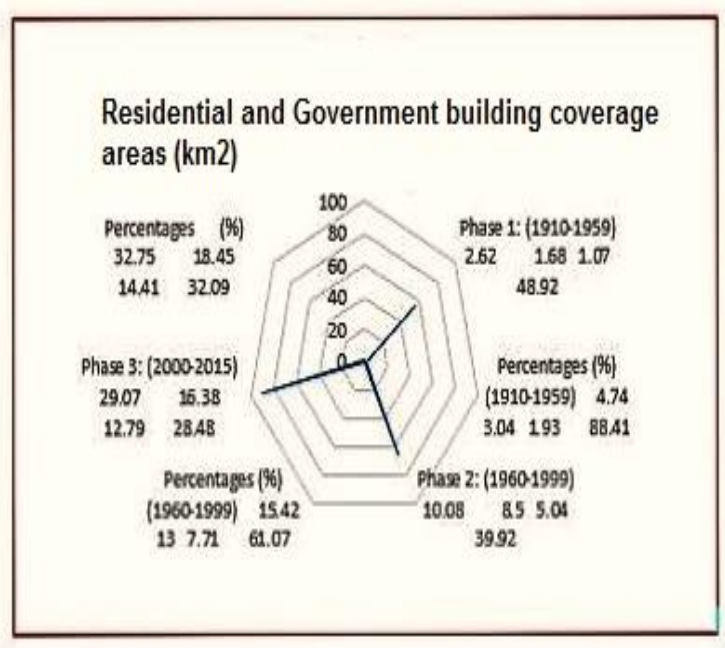

Figure 6. Land use coverage by the residential and Government structures $(\mathrm{Km} 2)$

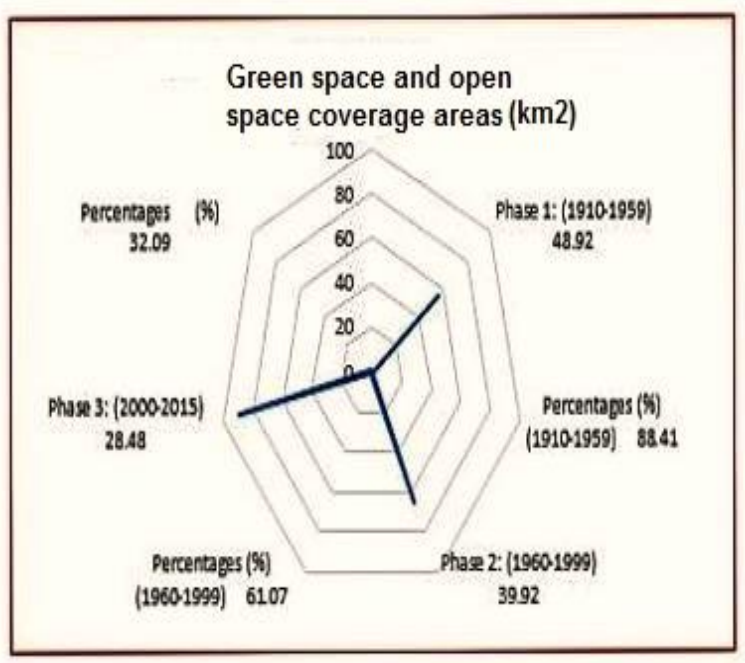

Figure 7. Land use coverage by the green space and open space areas $\left(\mathrm{Km}^{2}\right)$

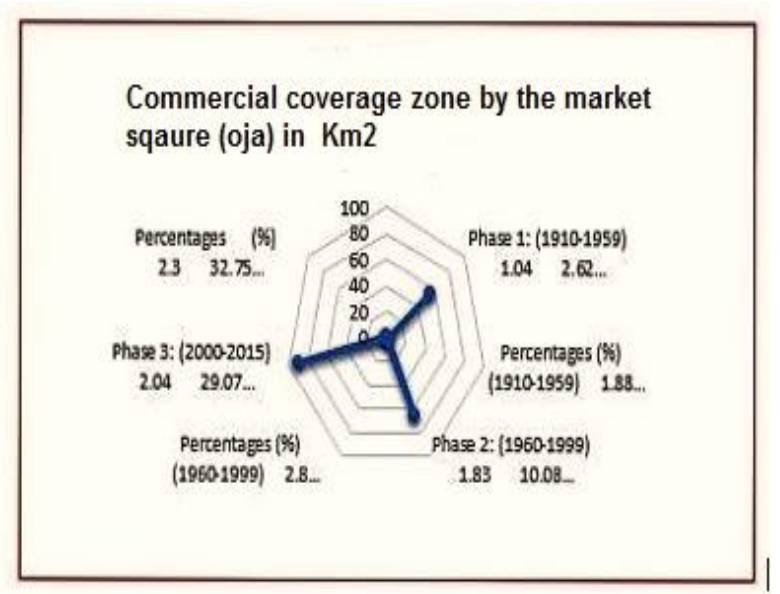

Figure 8. Land use coverage by the market square (oja) in $\mathrm{Km}^{2}$

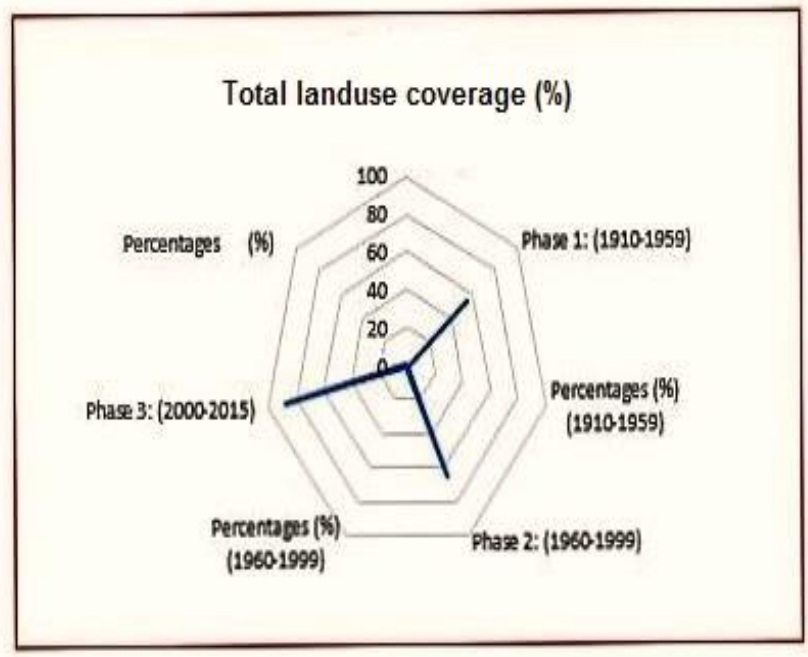

Figure 9.Total land use coverage $(\%)$

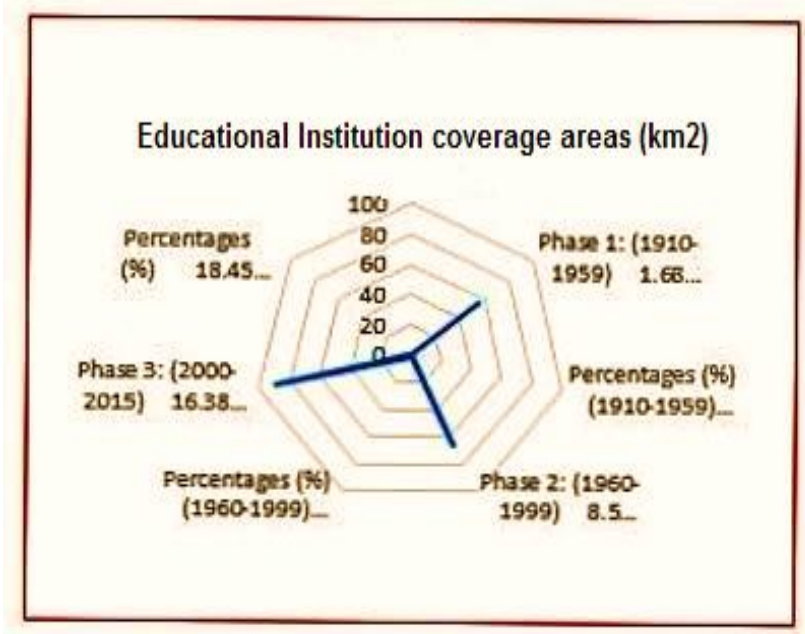

Figure 10. Land use coverage by the educational structures $\left(\mathrm{Km}^{2}\right)$ 


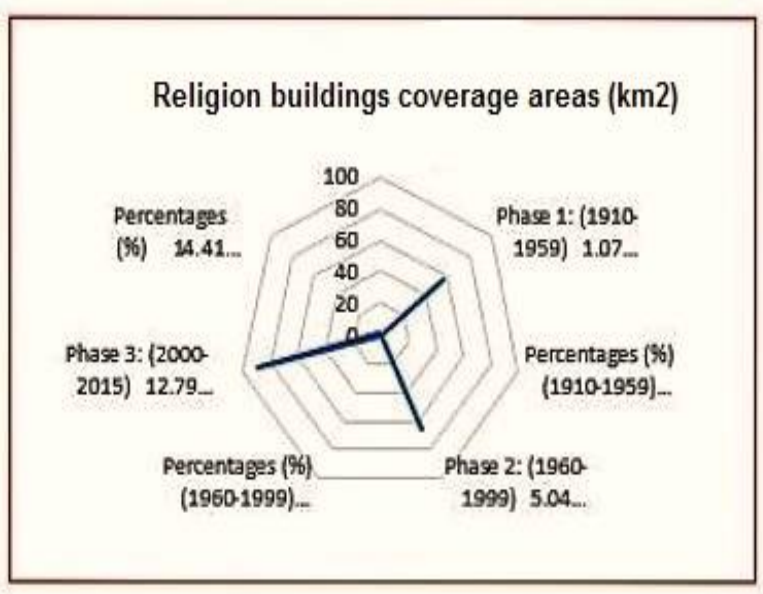

Figure 11. Land use coverage by the religion structures $\left(\mathrm{Km}^{2}\right)$

\subsection{Perceived inhabitants' activities on the neighbourhood characteristics and preferences}

The non-parametric results of a total number of 18 collated survey questionnaires were reflected in Figure 12 and Table 1. The mean and the relative importance index (RII) analysis presented the followings: (i) respondents' accessibility to the neighbourhood [RPN1] exhibited mean value of 4.61 and relative importance index of 0.92 ; (ii) neighbourhood safety [RPN2] revealed a mean values of 4.11; and relative importance index of 0.82; (iii) respondents' socialization within the neighbourhood [RPN3] showcased a mean values of 3.77 and relative importance index of 0.76; (iv) respondents' perception of neighbourhood attractiveness [RPN4] depicted a mean values of 3.11 and relative importance index of 0.62; ( $v$ ) neighbourhood spaciousness via the adequacy of market square conditions and green infrastructures [RPN5] showed a mean values of 2.27 and relative importance index of 0.45 .

From the aforementioned, accessibility to the neighbourhood ranked 1st indicating inhabitants gave the highest priority in appraising the suitability of the neighbourhood in the provision of excellent vehicular and pedestrian accessibilities. In other words, the neighbourhood accessibility has been considered in this study as an important aspect of sustainable neighbourhood development, particularly in the social well-being dimension as supported by past study of (Lynch et al., 2011). Accessibility remains the basic requirements to meet residents' free entry thus tends to enhance residents' quality of living (Lau \& Chiu, 2003; Landry \& Chakraborty, 2009). More importantly, accessibility was identified as an important aspect of environmental determinants for residents' physical activity. Ranked 2nd was the neighbourhood safety. The security and safety available in the neighbourhood space influence the quality attached by the residents. This is in line with the previous study of McCormack \& Shiell (2011) in which the residents' safety is considered vital in the overall neighbourhood design.

Socialization within the neighbourhood signified interactions among the diverse ethnic residents. Thus, it is ranked 3rd in the hierarchy. The result of the survey demonstrated that the neighbourhood forms could allow interaction among residents. Due to the low ranking, it is expected that an improvement is needed in the provision of adequate benches, walkways, seat out among others. This is corroborated by the researchers in the field of urban design and planning in which neighbourhood space established as an essential ingredient for social interaction and daily life experience (Madanipour, 1992; Worpole, 1992; Calthorpe, 1993; Pasaogullari \& Doratli, 2004). The outcome of the analysis placed respondents' perception on neighbourhood attractiveness 4 th in the rank. The attractive appearance of the neighbourhood could be judged in terms of the level of upkeep, variety in housing styles and street landscape, settings and fittings (Sallis, Bauman, \& Pratt, 1998). Similarly, it relates to the perception of the physical judgment of neighbourhood by the residents via its aesthetics.

However, the low ranking in the residents' perception in this respect suggests a need for an improvement and proper maintenance. Advocacy for proper neighbourhood facilities and amenities would better enhance its beauty and attractiveness. Last ranked(5 $\left.5^{\text {th }}\right)$ was ascribed to residents' perception of the neighbourhood spaciousness via the provision of the welllandscaped market square and green infrastructures. This lowest ranking indicates that much effort is needed to enhance neighbourhood spaciousness. The design and planning of neighbourhood open spaces remain 
a vital factor in its accessibility. Meanwhile, the spatial design of neighbourhood open spaces and its accessibility influence people's choice (Landry \& Chakraborty, 2009).

Table 1. Result of the perceived inhabitants' activities on the neighbourhood characteristics and preferences

\begin{tabular}{|c|c|c|c|c|c|c|c|c|c|c|c|}
\hline \multicolumn{12}{|c|}{ Frequencies of response } \\
\hline Vuriables & Codes & $\begin{array}{c}\vdots \\
\text { (Strungly } \\
\text { Agrete) }\end{array}$ & $\begin{array}{c}4 \\
\text { (Agreet) }\end{array}$ & $\begin{array}{c}3 \\
\text { (Meutral) }\end{array}$ & $\begin{array}{c}2 \\
\text { (Disigreet) }\end{array}$ & $\begin{array}{c}1 \\
\text { (Strongly } \\
\text { Disagrete) }\end{array}$ & \pm & 政 & Mean & RII & Rank \\
\hline $\begin{array}{l}\text { Accessblitity to } \\
\text { the } \\
\text { negrbhourhood }\end{array}$ & RPNI & 14 & 3 & 0 & 0 & 1 & 18 & 83 & 4.61 & 0.92 & $18 t$ \\
\hline $\begin{array}{l}\text { Naglbourhood } \\
\text { sadty }\end{array}$ & RNN2 & 12 & 2 & 0 & 2 & 2 & 18 & 74 & 411 & 0.82 & $2 \mathrm{nd}$ \\
\hline $\begin{array}{l}\text { Scialization } \\
\text { within tha } \\
\text { neighbourhood }\end{array}$ & RPN3 & 9 & 4 & 0 & 2 & 3 & 18 & 68 & 3.77 & 0.76 & $3 r d$ \\
\hline $\begin{array}{l}\text { Level of } \\
\text { neighounhood } \\
\text { attractiveners }\end{array}$ & RPN4 & j & 4 & 1 & 4 & 4 & 18 & 56 & 3.11 & 0.62 & 4th \\
\hline 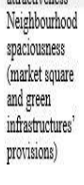 & RPNS & 3 & 2 & 0 & 5 & 8 & 18 & 41 & 2.27 & 0.46 & 5 th \\
\hline
\end{tabular}

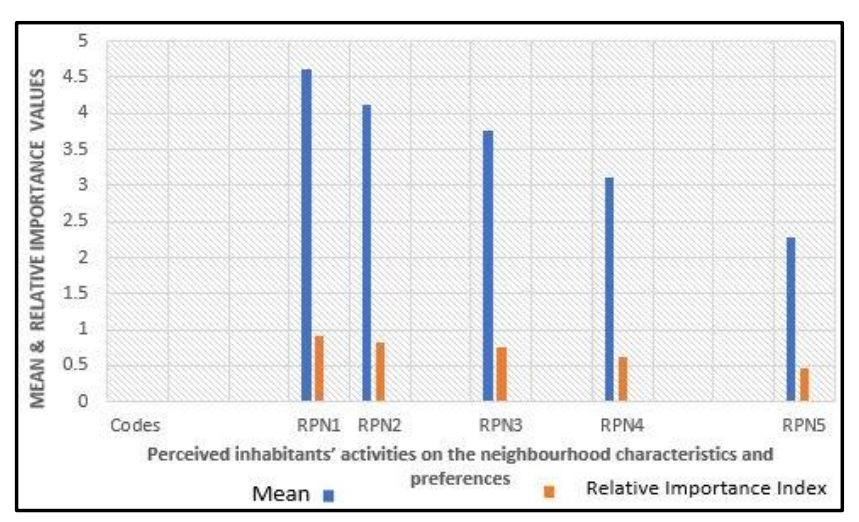

Figure 12. Perceived activities on the neighbourhood characteristics and preferences.

\section{Conclusion and Recommendation}

The study fills the knowledge gap by identifying the morphology of a rural neighbourhood as showcased by the residents' perception and character favouring future rural planning and design in Nigeria.Additionally, the combination of quantitative and qualitative of this study through relative importance index and the GIS-model allows documentation of neighbourhood comparative studies in Nigeria. The uniqueness of this study relies on the fact that it depicted rural landscape information that intertwines with social information on a neighbourhoodlevel. This allows a better insight into the various deficiencies in
Nigerian rural setting. Each transformation period was intertwined with driving forces such as accessibility, urbanization, and globalization.

Meanwhile, the challenges associated with every phase were as a result of the nature of the rural neighbourhood, the pace of the changes, and peoples' perception of the landscape. In other words, the quality of neighbourhood spaces impacts on citizens' patterns of activities. This study approach encircled the classic relationship between people and the sustainability of the neighbourhood environment as a means of enhancing residents' well-being and social needs. As established in this study, the social fragmentation of the rural landscape, however, has not been given dueconsiderations. The major originality of this research lies in the attempt to bridge a gap between the quantitative and qualitative study of rural neighbourhood towards the future design and planning practices. This research thus recommends adequate planning and design of neighbourhood and its adjoining spaces by the professionals and other relevant stakeholders for neighbourhood inhabitants in Nigeria. The knowledge gained from the outcome of the research could be made operational as an integrated monitoring tool that could be adopted by the three levels of government (local, state and federal authorities) in Nigeria.

\section{References}

Adejumo, T., Okedele, N., \& Adebamowo, M. (2012). Symbolism in the Conceptualization of Contemporary Yoruba City Central Business District Urban Design. Architecture and Urban design, Vol. 3, pp. 967-976. Epoka. http://dspace.epoka.edu.al/handle/1/287? show =full

Aderamo, A. J. and Magaji, S. A. (2010). Rural transportation and the distribution of public facilities in Nigeria: a Case study of Edu Local Government Area of Kwara State. Journal of Human Ecology, 29(3): 171-179. https://doi.org/10.1080/09709274.2010.11906260

Agboola, O. P., Rasidi, M. H., \& Said, I. (2017). Adolescents' Sense of Community and Involvement in Playground Activities: Panacea to Ameliorate Social Vices and Delinquencies. 
International Journal of Built Environment and Akinci G (1996). A study on the determination of the $\begin{array}{llll}\text { Sustainability, } & 4 & \text { (2), 81-92. }\end{array}$ http://doi.org/10.11113/ijbes.v4.n2.179.

Agboola, O. P., Rasidi, H. M., Zakka, S., D., Said, B \& Wahab Shuaibu, A. (2018). Residents' Social Interactions in Market Square and Its Impact on Community Well-Being. Journal of Contemporary Urban Affairs, 2(2), 24-32. Retrieved from: https://doi.org/10.25034/ijcua.2018.3668

Agboola, O. P., Rasidi M. H. \& Said I. (2015a): Neighbourhood Open space as Cultural Heritage Value in Multi-ethnic Community of South-West Nigeria. Asian Journal of Humanities and Social Studies. (ISSN: 2321 - 2799) Volume 03, Issue 01, Pp38-50.

https://ajouronline.com/index.php/AJHSS/article/ view/2084

Agboola, O. P., Zango M.S. \& Zakka S. M. (2015b): Towards Sustainability of Open Space's Planning and Management in Nigeria: Roles of Science and Technology". Jurnal Teknologi. Vol.77, No 14. Pp 51-56. https://doi.org/10.11113/jt.v77.6446

Agboola O.P. (2016). Rural Sense of Community of Oja in Nigeria. Unpublished PhD Thesis Submitted to School of Postgraduate Studies, Universiti Teknologi Malaysia. http://builtsurvey.utm.my/hisham/phd-students/

Agboola O.P., Rasidi, M.H., Said I. (2016). Residents' Contribution towards Improving Physical Quality of Neighborhood Open Spaces in Multi-Cultural Community of Nigeria. Journal of Advanced Research in Social and Behavioural Sciences. 2 (1). $\quad \mathrm{Pp}$ 95-92. http://www.akademiabaru.com/doc/ARSBSV2_N 1 P75 92.pdf

Agboola O. P. \& Salawu R. A. (2015). Examining the Role of Architects Vis-A-Vis Quantity Surveyors in The Building Industry at South West, Nigeria. International Journal of Research in Social Sciences. Vol. 04, No.9. 79- 89. http:// www.jjsk.org/ijrss

Ahmed Y.A. (2009). Settlement pattern and functional distribution in emerging communities: A case study of a local Government area of Kwara State, Nigeria. The social sciences, 4 (3): 256-263. ISSN:

1818-5800.

https://www.medwelljournals.com/abstract/?doi =sscience. 2009.256 .263

problems in open green spaces of Duzce city and actions to be taken. Abantizzet Baysal University Publications.

No: 5.

https://www.slideshare.net/AgboolaPaul/ruralmorphology-of-nigerian-town-a-quest-towardsameliorating-challenges-in-land-use-activities-

patterns

Appleyard, D. (1981). Livable Streets. Berkeley and Los Angeles, CA: University of California Press. https://www.amazon.com/Livable-Streets-

Donald-Appleyard/dp/0520047699

Atanda, J. A. (2007). A comprehensive history of the Yoruba people up to 1800 (G. O. Oguntomisin, Ed.). Ibadan, Nigeria: John Archers. https://www.academia.edu/34865427/KNIGHTS OF_A_GLOBAL_COUNTRYSIDE_THE_BALOGUN_INST ITUTION_OF_IJEBULAND_NIGERIA_I

Aydin, D. \& Büyük, S. (2014). "Neighborhood" Concept and the Analysis of Differentiating Sociological Structure with the Change of Dwelling Typology. Procedia - Social and Behavioral Sciences 140. Pp 260-269. https://doi.org/10.1016/j.sbspro.2014.04.418

Barclay, C. (2011). Eco-towns. Standard note: SN/SC/4406. London: House of Commons Library. Retrieved August 1, 2017, from http://www.parliament.uk/briefing-

papers/SN04406.pdf

Berk, M. G. (2005). The concept of the neighbourhood in contemporary residential environments: An investigation of occupants' perception. Paper presented at the International Conference on Doing, Thinking, Feeling Home, Delft, The Netherlands. Online at https://repository.tudelft.nl/islandora/object/uvid \%3Ae5868f2b-926c-428f-8b44-0a8c50cdd077

Boblic,T. (1990). The Role of Time Function in City Spatial Structure Past and Present, Gower Publishing Co Ltd, UK, p.25-51. http://eprints.unsri.ac.id/3962/1/ugm igsci 2011.p df

Hernández, B.M. (2013). The significance and meanings of public space improvement in lowincome neighbourhoods 'coloniaspopulares' in Xalapa-Mexico. Habitat International, 38. Pp 3446. https://doi.org/10.1016/j.habitatint.2012.09.003 Brail, R.K., Klosterman, R.E., (2001). Planning Support Systems, ESRI Press, Redlands, CA. Briassoulis. 
Bramley, G. \& Power, S. (2009). Urban form and Fadamiro, J.A., and Atolagbe, A.M.O (2006). Urban social sustainability: the role of density and housing type. Environment and Planning B: Planning and Design, 36, 30-48. http://www.whatifinc.biz/Resources/New_Tool.pd f

Centanni, Evan. (2017). Factors That Influence Settlement Patterns. Synonym. Retrieved from http://classroom.synonym.com/factors-thatinfluence-settlement-patterns-12080006.htmll

Chen, F. (2011). Traditional Architecture Forms Market-Oriented Chinese Cities: Place for Localities or symbol of culture. Habitat International, 35, 410-418. Elsevier. https://doi.org/10.1016/j.habitatint.2010.11.012 Environmental Sustainability: A Challenge to Effective Landscaping in Nigeria. DimensiTeknikArsitekur 34(1), 44-51. http://dimensi.petra.ac.id/index.php/ars/article/v iewFile/16456/16448

Falade, J. B. (1989). Amenity and Open Space Planning in Nigeria. Land Use Policy, 162-171. https://doi.org/10.1016/0264-8377/89)90042-2

Francis, J., Giles-corti, B., Wood, L., \& Knuiman, M. (2012). Creating Sense of Community: The Role of Public Space. Journal of Environmental Psychology, 32 (4), 401-409. doi: 10.1016/j.jenvp.2012.07.002.

https://doi.org/10.1016/i.jenvp.2012.07.002

Commonwealth Department of Communications and the Arts .(1995). Mapping Culture (Canberra, Commonwealth of Australia). https://trove.nla.gov.au/work/21514136? q\&versio nld $=45482944$

Collins, M.G., Steiner, F.R., and Rushman, M.J., (2001). Land-use suitability analysis in the United States: historical development and promising technological achievements. Environmental Management $28 \quad$ (5), 611-621. https://doi.org/10.1007/s002670010247

Dave, S. (2011). Neighbourhood density and social sustainability in cities of developing countries. Sustainable Development, 19(3), 189- 205. https://doi.org/10.1002/sd.433

Dempsey Nicola, Bramley Glen, Power Sinéad, and Brown Caroline (2009). The Social Dimension of Sustainable Development: Defining Urban Social Sustainability Sustainable Development Journal, 19(5), 289-300. https://doi.org/10.1002/sd.417

Doralti N. (2004). An Analytical Methodology for revitalization strategies in Historic Urban Quarters: A case study of the walled city of Nicosia, North Cyrus, Cities, 21 (4), 329-384. Elsevier. https://doi.org/10.1016/j.cities.2004.04.009

Duxbury N. and Campbell, H. (2011). Developing and Revitalizing Rural Communities through Arts and Culture. Small Cities Imprints, 3 (1). https://www.researchgate.net/profile/Nancy Dux bury/publication/307631801_Developing and_Re vitalizing_Rural_Communities_through_Arts_and_C ulture/links/551b0d1f0cf2fdce843850a9/Developi ng-and-Revitalizing-Rural-Communities-throughArts-and-Culture.pdf

French, S., Wood, L., Alexandra, S., Giles-corti, B., Frank, L., \& Learnihan, V. (2014). The sense of Community and Its Association with the Neighborhood Built Environment. Environment and Behavior, Vol.46 (6), 677-697. https://doi.org/10.1177/0013916512469098

Goodall, B. (1987). The Penguin Dictionary of Human Geography, Harmondsworth: Penguin. https://www.abebooks.co.uk/book-

search/title/penguin-dictionary-humangeography/author/goodall/

Gordon, D. (1984), "The Shaping Of Urban Morphology", In D. Reeder (Ed.), Urban History Yearbook 1984," Leicester: Leicester University Press, Pp. 1-10. http://www.urbanform.org/online_unlimited/um2 00002_63-77.pdf

Herbert, D. and Thomas C. (1982), Urban Geography, Chichester: John Wiley. http://www.bristol.ac.uk/geography/media/ronjo hnston/PublicationsListApril2013.pdf

Herzele, A. Van, \& Wiedemann, T. (2003). A monitoring tool for the provision of accessible and attractive urban green spaces. Landscape and Urban Planning. 63(2), 109-126. https://doi.org/10.1016/50169-2046(02)00192-5

Janssen, R., Rietveld, P., (1990). Multi-criteria analysis and geographical information systems: An application to agricultural land use in the Netherlands. In: Scholten, H.J., Stillwell, J.C.H. (Eds.), Geographical Information Systems for Urban and Regional Planning, Kluwer Academic Publishers, Dordrecht, pp. 129-139. 
https://link.springer.com/chapter/10.1007/978-94017-1677-2 12

Kallus, Rachel, and Hubert Law-Yone. (2000). "What is a Neighbourhood? The Structure and Function of an Idea." Environment and Planning B: Planning and Design 27 (6): 815-826. https://doi.org/10.1068/b2636

Kazmierczak, A. (2013). The contribution of local parks to neighbourhood social ties. Journal of Landscape and Urban Planning. 109(1), 31-44. https://doi.org/10.1016/j.landurbplan.2012.05.007

Lynch Amy J., Andreason Stuart, Eisenman Theodore, Robinson John, Steif Kenneth, and Birch Eugenie L. (2011). Sustainable urban development indicators for the United States, Penn IUR White Paper Series on Sustainable Urban Development.

(Report). https://www.researchgate.net/publication/28124 1372 Sustainable_Urban_Development_Indicators for_the United_States

Meenakshi (2011). Neighborhood Unit and its Conceptualization in the Contemporary Urban Context. Institute of Town Planners, India Journal, 8 - 3, July - September 2011, 81 - 87. http://www.itpi.org.in/files/jul10_11.pdf

Middleton, J. (2010). Sense and the city: exploring the embodied geographies of urban walking. Social \& Cultural Geography, 11(6), 575-596. http://doi.org/10.1080/14649365.2010.497913

Miller, W., Collins, W.M.G., Steiner, F.R., Cook, E., (1998). An approach for greenway suitability analysis. Landscape and Urban Planning 42 (2-4), 91-105.https://doi.org/10.1016/s0169-

2046(98)00080-2

Na, W., Weimin, G. and Qinfang, G. (2009). The research on the development of the form on the Urban public space in China in the periods of 1949-2008. Proceedings of the IEEE 10th International Conference on Computer-Aided Industrial Design and Conceptual Design, CAID and CD, 2009. 26-29th November in Wenzhou, pp 2184-2188. 10.1109/CAIDCD.2009.5375115

Nadeem, O., Hameed, R., \& Zaidi, S. S. (2013). Residents' Perception and Analysis of the Contemporary Neighbourhood Design Practices in Lahore, Pakistan. Pak. J. Engg. \& Appl. Sci., 12, 143-158.

http://journal.vet.edu.pk/ojs_old/index.php/pjeas /article/view/137
Oduwaye A O (1998). Urban landscape planning experience in Nigeria. Landscape Urban Planning 43(1-3):133-142. https://doi.org/10.1016/s01692046(97)00013-3

Officha, M.C., Onwuemesi, F.E. \&Akanwa, A.O. (2012). Problems and Prospect of Open spaces Management in Nigeria: The Way Forward. World Journal of Environmental Biosciences. Volume 2, Issue 1: 7-12.

https://www.google.com/urlesa=t\&rct=j\&q=\&esrc $=s \&$ source $=$ web \& $c d=1 \& c a d=r j a \& v a c t=8 \& v e d=2$ ahUKEwi464Kb57DfAhWEgaQKHUs7AWQQFjAAeg QICBAC\&url=http\%3A\%2F\%2Fwww.environmentalj ournals.org\%2Fadmin\%2Farticles\%2FDownloadArc ivePDF\%2FWJEB-2013-2-1-

22.pdf\&usg=AOVVaw1lkHYH-MK64edRx-ZU-b7m

Okoro Cyprian Friday (2012). Democracy and Good Governance in A Multi-Ethnic Society: Nigeria As A Case Study. A Grassroots Study of the Igbo, Yoruba and the Hausa-Fulani Ethnic Nationalities. Dissertation submitted to the Faculty of Humanities of the Philipps University Marburg in fulfilment of the requirements for the degree of Doctor of Political Science and Social Sciences. https://archiv.ub.uni-marburg.de/diss/z2014/0436/ Onwuanyi, N. (2017). Remaking Nigeria's Urbanism: Assessing and Redressing the Dearth of Open Spaces in Benin City. International Journal of Built Environment and Sustainability, 4 (2), 121-130. http://doi.org/10.11113/ijbes.v4.n2.183

Oyesiku, K. (1998). Modern Urban and Regional Planning Law and Administration. Ibadan: Kraft Books

Ltd.

https://searchworks.stanford.edu/view/4100364

Peters, K., Elands, B., \& Buijs, A. (2010). Social Interactions In Urban Parks: Stimulating Social Cohesion? Urban Forestry \& Urban Greening, 9, 93-100. https://doi.org/10.1016/i.ufug.2009.11.003 Pillai, J. (2013). Cultural Mapping: A Guide to Understanding Place, Community, And Continuity (1st edition). Petaling Jaya: Malaysia: Strategic Information and Research Development Centre, Universitisains Malaysia.

http://www.gtwhi.com.my/educate/talksseminars-and-workshops/public-talks/previoustalks-and-seminars/222-cultural-mappingunderstanding-place-community-andcontinuity.html 
Rescia, A. J., Pons, A., Lomba, I., Esteban, C., \& Dover, J. W. (2008). Reformulating The SocialEcological System In A Cultural Rural Mountain Landscape In The Picos De Europa Region (Northern Spain). Landscape and Urban Planning, $88(1)$, 23-33.

https://doi.org/10.1016/i.landurbplan.2008.08.001

Shamah, Devora, and Katherine MacTavish. (2009). "Rural Research Brief: Making Room for Placebased Knowledge in Rural Classrooms." The Rural $\begin{array}{llll}\text { Educator } \quad 30 & \text { (2), } & \text { 1-4. }\end{array}$ https://files.eric.ed.gov/fulltext/EJ869303.pdf

Stephenson, J. (2010). People and Place, Planning Theory \& Practice, 11:1, 9-21, https://doi.org/10.1080/14649350903549878

Song, Y. \& Knaap, G. J. (2003). New urbanism and housing values: A disaggregates assessment. Journal of Urban Economics, 54(2), 218238.https://doi.org/10.1016/s0094-1190/03)00059-7 Whitehand, J. W. R. (1987), "Urban Morphology", in M. Pacione (ED.), Historical Geography. Progress and Prospect, London: Croom Helm Ltd., PP. 249256.

https://www.scribd.com/document/383843242/M orphological-and-GIS-based-land-use-Analysis-ACritical-Exploration-of-a-Rural-Neighborhood

Worpole, K. (1992) Towns for People: Transforming Urban Life. Buckingham: University Press. Wiley West.

Weir, L. J and McCabe, F. (2012) Towards a Sustainable Rural Transport Policy: from http://www.irishrurallink.ie (Retrieved October 20, 2013).

Yildiz N.D; Demir M.; and Yilmaz S. (2011). Determination of the efficiency of green areas in Erzurum City. Scientific Research and Essays. Vol. 6 (2), pp. 293-304. Available at: http://citeseerx.ist.psu.edu/viewdoc/download?d oi=10.1.1.885.2052\&rep=rep 1 \&type=pdf 